\title{
How Activism on Gender and Sexuality is Changing Museums
}

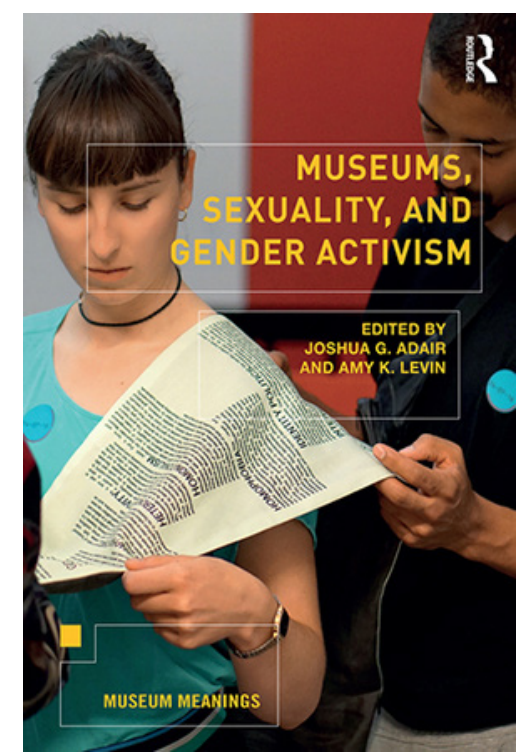

Joshua G. Adair and Amy K. Levin (eds). 2020. Museums, Sexuality, and Gender Activism. London: Routledge, 306 pages.

Museums, Sexuality, and Gender Activism is a collaboration between artists, activists, curators and scholars, and these roles are often overlapping, challenging easy distinctions and categories. In all, the volume has 32 different authors.

As I myself have recently changed my main working situation from activism to academia I find it especially interesting to read practical examples of how others make these changes work in a productive way. The anthology offers many great examples of the necessity of activism, in the sense of action, to make changes in old structures possible. The locations and contexts of the book is a collage spanning over a vast number of countries and times, even though most exhibitions and actions take place within the last ten years. This offers a myriad of openings to the book and makes it a relevant tool for understanding museums engagement with questions of gender more broadly than in the examples described in the book itself.

Joshua G. Adair and Amy K. Levin's (ed.) anthology Museums, Sexuality, and Gender Activism is a continuation of Gender, Sexuality, and Museums: A Routledge Reader (Levin, ed. 2010). This new volume, in Levin's words, fills gaps by presenting newer content. Still this anthology stands strongly by itself and does not need to be read as a supplement to the former book. The book is built by five different parts: Frameworks, Dismantling the Master's House?, Bodies in the Museum?, Acts of Resistance and Thinking Outside the Binary Box. In some cases these have in turn two separate subgenres; overall there are 24 texts that build a multilayered but cohesive totality. Reviewing the book as a whole is a challenge since it is often in the details that it contributes most. The book's extensive index is a sign that the reader is invited to also use the text as an encyclopedia - with the warning that you might end up with more questions than answers. As it should be when you are dealing with gender activism and museums.
Queer Eye

Reviews

Nina Nyman 
A highly enjoyable part of reading, that should not be underestimated, was all the rich description of works of art and spaces where they have been created or displayed. Reading the collection in the spring of Covid-19 gave me a sense of visiting new places.

\section{Engaging with museums through activism}

At the heart of the book is a question of what the responsibilities of museums are and who is working with fulfilling these responsibilities. The common theme in the book is about engaging with harmful practices, through a critique that is an act of care. Critique takes place on many layers, and the editors of the anthology are involving themselves in it not only in their book, but also of the book, by "acknowledge[ing] exclusion rather than to pretend that completeness is possible" (Levin, 13). Stating failures is here seen not as an endpoint, but rather as a starting point for new possibilities. The actions described in the book, but also writing the book itself, becomes a positive response to a negativity of lack.

Amanda K. Figueroa in her chapter "Chicana Feminism, Anzalduian Borderland Practices, and Critiques of Museology" sums up one side of the problem very well when she writes, "It is only when power structures are completely visible that the processes of knowledge and culture production at work in museums can be discussed and altered" (26). Still, it is important to highlight the ways in which museums' power structures are made visible in many of the books chapters, namely through cultural production and alteration. These processes are not necessarily separate from each other, and most certainly never finished.

\section{Categorization, classification and mislabeling}

In his "Bodies in the Museum?",an introduction to Part III of the book, “ Adair highlights that museums traditionally have "held 'Enlightenment' values of categorization and classification" (127). At times I find that the book struggles somewhat with the same dilemma. By presenting what is missing, you risk simply adding new categories. Still, many chapters brilliantly depart from this logic by engaging disruptively, or even queerly, with the categorization and classification process.

One of the best examples of this is the chapter "Nonbinary Difference: Dionysus, Arianna, and the Fictive Arts of Museum Photography” by Åsa Johannesson and Clair Le Couteur. In the text we encounter photographs of the same object taken in different times, angles and lights, and attached with different labels, or even (at least once) mislabeled. The authors use the mislabeling as an invitation to a reading evoking for me Deleuze and Guattari's concept of becoming, where the object of the photograph and the photograph as object keep traveling between Dionysus, Arianna, and, maybe, Arianna.

Johannesson and Le Couteur write that "Mislabeling has material consequences and leaves traces; myths, too, many have tangible effects" (167). In their case mislabeling becomes queering, but in other cases, mislabeling is identified as a means to write away racist histories or keep queer pasts hidden. The common thread in the book is that mislabeling might shift responsibility and power of interpreting the art and the museum space to the viewer, exposing that art and museums are not always what they claim to be, and reminding us of how different temporalities will shift circumstances for interpretation. That the viewer has the power and possibility of interpretation may sound like a given, but what the anthology skillfully demonstrates are the invisible (and sometimes visible) frames of 
interpretations a museum or gallery creates when building an exhibition. The book offers positive examples of how challenging these frames creates a more inclusive environment.

Categorization and classification has at least as strong of a hold to academic writing as it has on museum exhibitions. Communicating gender activism first as a piece of art, then having that curated in a museum exhibition, then analyzed and expressed in an academic settings, such as in this book, and then further being read and analyzed as a text by me, and finally being read as review by you offers many potential traps of convenient categorizations. It also makes me ask, how this anthology would have looked and felt as an exhibition rather than a book?

\section{The Labor of Art}

An underlying current in the book is the labor of art. Whose job is it and who should pay for it? What is the role of money in museums? The question is posed in the beginning of the anthology, and it also frames whose voice is heard in it. Some people could not participate in the book since the project could not offer necessary funds, as it often is in the case in both academia and arts. The same pattern runs through many of the projects described in the chapters of the book. Since the need for compensation for time spent is not equal, it can create a tension in the concept of activism that (often) by definition is not paid.

The anthology offers many ways of understanding the role of paid labor and activism when it comes to making art and working with museums. In Tuan Nguyen's chapter "Pop-up or Permanent? The Case of the Mardi Gras Museum" he brings forth positive sides of pop-up museums that are explicitly tied to the lack of formal responsibilities that are an inevitable part of financial contracts. In contrast to this, one can read
Catherine O'Donnell's chapter “Never Going Underground: Community Coproduction and the Story of LGBTQ+ Rights". She describes amongst other financial issues a situation where the project she was involved with did have some money, but where the financers allowed the train tickets of participants only to be reimbursed afterward. This created a situation that made it difficult for asylum seekers to participate since they in the UK receive only $£ 37.75$ a week and are prohibited from earning money (225).

Another interesting question that the anthology raises about labor is about the role of emotional labor in museums and how it should be compensated. This is of course a question that should not be given an universal answer, but one that needs to be discussed continuously, especially when museums work with groups that are often only heard with the prerequisite that they give the public access to their own personal stories. Still, the anthology offers many examples of when the emotional labor has been respected. Such entries can be used to give ideas on how new projects can work.

\section{Going forward}

Zorian Clayton and Dawn Hoskin in their chapter "Activists on the Inside: The Victoria and Albert Museum LGBTQWorking Group” offer a brief look back at what has happened in museums in regards to sexuality and gender activism in the last ten years. They write:

"Since the publication of Levin's 2010 collection, there has been a seismic shift toward greater inclusion of minority and underrepresented histories in museums. Key motivators for change include audible public demands, heightened governmental scrutiny, and the field 's increasingly diverse and outward-looking workforce." (57.)

Such a change is powerfully echoed also in this volume, and it is what we 
as readers can expect to see taking place also in the future, I hope. The anthology places itself firmly in this tradition of "audible public demands, heightened governmental scrutiny, an increasingly diverse and outward-

looking workforce" (57) in museums. As such it offers rich possibilities for the reader to engage with museums and gender activism, preferably in combination. Since the book is so rich in details it is easy to see how

it can be used as a hands-on guide when working in/with museums and in building exhibitions. The fact that this book is a follow-up for its predecessor is also a reminder of the importance of learning from and

building on previous experiences.

\section{References}

Levin, Amy K. (ed.). 2010. Gender, Sexuality, and Museums: A Routledge Reader Abingdon, Oxon: Routledge. 